\title{
MATERI CIVIC EDUCATION MAMPU MEMBENTUK KARAKTER PESERTA DIDIK
}

\author{
Herdi Wisman Jaya \\ Fakultas Keguruan dan Ilmu Pendidikan, Universitas Pamulang \\ herdiwismanjaya@gmail.com
}

\begin{abstract}
Abstrak
Materi Pendidikan Kewarganegaraan (civic education) mampu membentuk karakter peserta didik di kelas VIII salahsatu MTs swasta di Kecamatan, Pamulang, Kota Tangerang-Selatan. Tujuan Pendidikan merupakan bagian dari kebutuhan setiap manusia untuk meningkatkan martabat manusia dan meningkatkan kualitas sumber daya manusia yang merupakan sumber daya utama dalam pembangunan yang lebih maju. Metode penelitian yang digunakan adalah metode survei yang merupakan bagian dari penelitian deskriptif kuantitatif. Data penelitian diambil menggunakan teknik random sampling dari jumlah populasi sebanyak 52 peserta didik. Dari populasi ditetapkan sampel sebanyak 34 peserta didik. Instrument yang digunakan dalam pengumpulan data adalah berupa kuesioner dan nilai raport. Hasil Materi pendidikan kewarganegaraan mempunyai hubungan yang signifikan membentuk karakter peserta didik. Dari perhitungan hasil hipotesis yang dilakukan dengan menggunakan rumus korelasi product moment diperoleh harga indeks korelasi $r_{\text {hitung }}$ sebesar 2,345 sementara $r_{\text {tabel }}$ 0,339. Ini berarti $r_{\text {hitung }}$ lebih besar dari rtabel $(2,345>0,339)$. Selanjutnya untuk mengetahui tingkat keberartian kedua variabel tersebut diperoleh hasil $t_{\text {hitung }}$ pada taraf signifikansi $\quad(a)=0,05$ sebesar 5,96 dan $t_{\text {tabel }}$ 1,697 dengan demkian $t_{\text {hitung }}$ lebih besar daripada $t_{\text {tabel }}(5,96>1,697)$. Hasil ini menunjukan bahwa koefisien korelasi product moment signifiken positif yang searah. Dalam hal ini maka dapat ditarik kesimpulan bahwa materi pendidikan kewarganegaran mampu membentuk karakter peserta didik, seperti halnya di MTs swasta daerah Pamulang Kota Tangerang Selatan.
\end{abstract}

Kata-kata kunci: materi pendidikan kewarganegaraan, karakter peserta didik

\author{
Jurnal Pendidikan Kewarganegaraan \\ Journal of Civics and Education Studies \\ The journal is published by Department of Civic Education \\ Faculty of Teacher Training and Education \\ Universitas Pamulang - Indonesia
}

Copyright $\odot$ 2017|ISSN: 2302-0865 


\section{PENDAHULUAN}

Pembangunan Nasional yang bertujuan untuk meningkatkan martabat manusia Indonesia dapat di laksanakan secara berhasil bila upaya pembangunan tersebut dapat meningkatkan kualitas Sumber Daya Manusia (SDM) yang merupakan sumber daya utama dalam pembangunan seperti terdapat dalam Undang-Undang No.20 Tahun 2003 Tentang Sistem Pendidikan Nasional mengamanatkan dengan tegas bahwa setiap warga negara berhak mendapat layanan pendidikan bermutu dan pendidikan bermutu tidak hanya di ukur dari produk (output) akan tetapi terkait dengan input dan proses dalam penyelenggaraan pendidikan. Oleh karena itu upaya meningkatkan mutu layanan pendidikan harus melibatkan stakeholder pendidikan khususnya masyarakat dan orang tua peserta didik. Maka untuk melaksanakan pembangunan seperti itu diperlukan suatu sistem administrasi pembangunan yang berkemampuan serta memberi peluang bagi peningkatan kualitas manusia Indonesia. Seperti di amanatkan dalam Undang-Undang No.20 Tahun 2003.

Dalam rangka meningkatkan sumber daya manusia, sudah banyak usaha yang telah di tempuh pemerintah. Pengembangan aktifitas dalam bidang pendidikan merupakan salah satu alternatif mengembangkan sumber daya manusia yang telah di upayakan pemerintah, oleh karena itu sumber daya yang ada perlu di tingkatkan kualitas dan kuantitasnya untuk menunjang pelaksanaan pembangunan negeri ini. Salah satu upaya untuk meningkatkan sumber daya manusia ini melalui pendidikan yang terintegrasi dengan baik. Dengan demikian manusia dapat menambah ilmu pengetahuan dan segala keterampilan yang dapat di gunakan dalam pembangunan serta pelaksanaan rencana pembangunan ke depan yang lebih baik bagi bangsa dan negara ini. Hal ini sesuai dengan Landasan Yuridis Pendidikan Kewarganegaraan bertujuan membentuk peserta didik menjadi manusia yang memiliki rasa kebangsaan dan cinta tanah air.

Pendidikan merupakan proses budaya untuk meningkatkan harkat dan martabat manusia. Dengan demikian bidang pendidikan menduduki posisi penting untuk menuju perkembangan dan kemajuan suatu bangasa. Sehingga tujuan pendidikan nasional di atas akan dapat tercapai apabila ada tanggung jawab dari semua pihak, karena secara historis dan teoritis bidang pendidikan di anggap begitu penting, karena mencerdaskan kehidupan bangsa. Melalui pendidikan kita mendidik manusia-manusia yang bermutu sehingga kita bisa memanfaatkan semua yang ada di sekitar kita, termasuk sumber daya alam (SDA) demi kepentingan manusia tanpa merusaknya.

Ada berbagai pembaruan normatif dalam konstitusi dan perundangundangan kita terkait dengan penyelenggaraan pendidikan nasional menandakan adanya komitmen yang tinggi dari bangsa kita untuk . mencerdaskan kehidupan bangsa melalui pendidikan dan 
pengajaran.Undang-Undang Dasar 1945 hasil amademen (pasal 31: 4) yang menetapkan bahwa negara memperioritaskan anggaran pendidikan sekurang-kurangnya dua puluh persen (20\%) dari Anggaran Pendapatan Belanja Negara". Di samping itu profesional guru kemudian mendapatkan penjelasan dan landasan operasional dalam UndangUndang nomor 14 tahun 2005 tentang Guru dan Dosen ( UU GD ). Dalam UU GD penataan dan peningkatan guru semakin dipertegas dengan menetapkan kualifikasi, kompetensi, dan sertifikasi Guru dan Dosen di seluruh pelosok negeri. Dengan kata lain, sebetulnya pendidikan berfungsi menelurkan perubahan melalui pendekatan nalar dan kreativitas untuk dapat meningkatkan kesejahteraan rakyat secara menyeluruh.

Sebagaimana diketahui bahwa banyak faktor yang dapat menghambat kemajuan belajar yang dapat mempengaruhi prestasi belajar mata pelajaran pendidikan kewarganegaraan. Hal ini sebagaimana Ahmadi dkk (1991:283) ${ }^{5}$ mengatakan, bahwa terdapat beberapa hal yang menghambat kemajuan belajar, tetapi pada pokoknya dapat di golongkan menjadi 2 faktor. Yaitu, pertama, Faktor indogin, yakni faktor yang datang dari diri peserta didik atau mahasiswa sendiri. Faktor ini meliputi Faktor biologis (faktor yang bersifat jasmaniah) Faktor psycologis ( faktor yang bersifat rohaniah). Kedua, faktor exogin, yakni faktor yang datang dari luar diri peserta didik atau mahasiswa yang meliputi lingkungan keluarga, lingkungan sekolah, lingkungan masyarakat (Ahmadi, 1991: 283). Faktor- faktor di atas ini merupakan sebagian dari banyak faktor yang mempengaruhi prestasi belajar pada peserta didik.

Termasuk dari kedua faktor diatas juga yaitu antara lain, pemahaman guru terhadap kurikulum Pendidikan Kewarganegraan, latar belakang pendidikan guru yang tidak sesuai dengan mata pelajaran yang ada, kurangnya penguasaan metodelogi pengajaran Pendidikan Kewarganegaraan oleh guru sehingga kadang-kadang dalam pengajaranya di kelas membuat peserta didik tidak menyenangi mata pelajaran Pendidikan Kewarganegaraan, masalah ketersediaan media dan alat peraga yang kurang mendukung serta penggunaaan sarana dan prasarana serta lingkungan sebagai sumber belajar yang kurang guna dan berhasil guna serta masalah alokasi waktu yang kurang memadai, yaitu jumlah jam yang tersedia tidak seimbang dengan luasnya bahan ajar mata pe' ıjaran Pendidikan Kewarganegaraan. Dalam mencapai tujuan mata pelajaran Pendidika Kewarganegaraan, dipengaruhi oleh beberapa komponen yang mendukung diantaranya pendidik, peserta didik, kurikulum, proses belajar mengajar (PBM), proses belajar mengajar, pada dasarnya meliputi materi, metode dan penilaian.

Pendidikan Kewarganegaraan seyogyanya diberikan dalam bentuk sistem yang utuh menyeluruh meliputi pola pikir dan pola sikap. Pola sikap peserta didik agar mampu melaksanakan hak-haknya dan kewajibanya untuk menjadi warga negara Indonesia yang terampil dan berkarakter sesuai yang di 
amanatkan oleh Pancasila dan UUD 1945. Pendidikan Kewarganegaraan mengajarkan peserta didik untuk mengenal aturan dasar kewarganegaraan, media untuk mengajarkan kehidupan politik, mendidik untuk lebih memiliki toleransi dan tenggang rasa, memberikan pengetahuan tentang peraturan negara yang mengikat agar peserta didik bisa hidup dalam aturan hukum yang berlaku, sarana untuk menumbuhkan rasa cinta tanah air.

Membahas tujuan Pendidikan Kewarganegaraan memiliki keterkaitan dengan fungsi Pendidikan Kewarganegaraan, karena keduanya saling berkaitan dimana tujuan materi merupakan dunia cita, yakni suasana ideal yang harus dijelmakan. Sedangkan fungsi adalah pelaksanaan-pelaksanaan dari tujuan yang hendak di capai oleh karena itu tujuan materi dan fungsi menunjukan keadaan gerak, aktifitas dan termasuk dalam suasana kenyataan. Kemudian misi mata pelajaran Pendidikan Kewarganegaraan, yaitu membentuk warga Negara yang baik yakni warga Negara yang sanggup melaksanakan hak dan kewajibanya dalam kehidupan bernegara, dilandasi oleh kesadaran hukum dan kesadaran moral. Untuk mewujudkan misi diatas, jelas bahwa peserta didik harus memiliki kemampuan kewarganegaraan yang baik agar dapat menjalankan hak dan kewajiban dalam berbagai aspek kehidupan, karena aspek kehidupan sangatlah penting. Aspekaspek tersebut diantaranya Aspek memahami Pengetahuan memahami keterampila kewarganegaraan (civic skils), dan aspek memahami etika kewarganegaraan (civic ethnic).

Selain itu apabila di pelajari dengan baik, mata pelajaran Pendidikan Kewarganegaraan dapat membentuk karakter dari peserta didik, karena mata pelajaran Pendidikan Kewarganegaran mengajarkan beberapa hal yang baik dan utama dalam proses kehidupan peserta didik di kemudian hari di dalam masyarakat. Oleh karena itu maka mata pelajaran Pendidikan Kewarganegaraan pun menjadi sangatlah penting karena dapat membantu membentuk karakter peserta didik untuk menjadi individu dan warga negara yang baik.

\section{METODE PENELITIAN}

Metode penelitian yang di gunakan dalam penelitian ini adalah metode survey yang merupakan bagian dari penelitian deskriptif kuantitatif. Penelitian ini di maksudkan agar dapat menemukan pengaruh antara variabel-variabel yang di teliti yaitu materi Pendidikan Kewarganegaraan dengan karakter peserta didik. Melalui metode ini peneliti akan meneliti sejauh mana pengaruh antara variabel bebas yaitu Pendidikan Kewarganegaraan dengan variabel terikat yaitu karakter peserta didik.

Populasi target dalam penelitian ini adalah seluruh peserta didik disalah satu Madrasah Tsanawiyah (MTs) swasta daerah Pamulang, Kota TangerangSelatan, tahun 2014 yang berjumlah 862 peserta didik. Populasi terjangkau dari peserta didik yang menjadi penelitian ini 
adalah seluruh peserta didik disalah satu Madrasah Tsanawiyah (MTs) swasta daerah Pamulang, Kota TangerangSelatan, sebanyak 52 orang.

Dalam penelitian ini teknik yang di gunakan adalah random sampling sederhana yaitu jumlah populasi di tentukan jumlah sampel sebagai objek penelitian, pengambilan sampel dilakukan dengan cara undian yaitu kelas VIII untuk menentukan ukuran sampel dari suatu populasi dalam penelitian ini rumus yang di gunakan adalah teknik rumus solvin.

Data diambil melalui observasi di seluruh peserta didik disalah satu Madrasah Tsanawiyah (MTs) swasta daerah Pamulang, Kota TangerangSelatan. Adapun pengumpulan data dalam penelitian ini dilakukan dengan menggunakan instrumen angket, yaitu sektor materi Pendidikan Kewarganegaraan apa saja yang mampu membentuk karakter peserta didik atau responden, dan data karakter peserta didik berupa data ex facto yang di peroleh dari nilai raport peserta didik.

Dalam penelitian ini terdapat dua variabel, yaitu Materi Pendidikan Kewarganegaraan (X) sebagai variabel bebas dan karakter peserta didik sebagai variabel terikat $(\mathrm{Y})$ Instrumen penelitian ini menggunakan bentuk angket dengan pilihan jawaban sebagai berikut: Sangat setuju (SS), Setuju (S), Tidak Setuju (TS), Ragu-ragu (RR), Sangat tidak setuju (STS). Adapun indicator kuesionernya antara lain sebagai berikut : Sikap positif terhadap pancasila, Memahami pelaksanaan UUD 1945, Mematuhi peraturan perundang-undangan NKRI,
Berdemokrasi dalam keseharian, dan Memaknai kedaulatan rakyat. Kemudian untuk dapat memperoleh i\ndikator instrument yang baik, maka dilakukan beberapa ujicoba antara lain, uji validitas, dan uji reabilitas instrument. Selain itu juga dilakukan Uji persyaratan Analisis meliputi, Uji Normalitas, dan Uji Linieritas.

\section{HASIL DAN PEMBAHASAN}

\section{Deskripsi Variabel $\mathrm{X}$ (Pendidikan Kewarganegaraan)}

Pendidikan

Kewarganegaraan sebenarnya dilakukan dan dikembangkan di seluruh dunia meskipun dengan berbagai istilah atau nama. Mata pelajaran tersebut sering juga disebut sebagai civic education, citizenship education, dan bahkan ada yang menyebut sebagai democracy education. Mata pelajaran ini memiliki peran yang strategis dalam mempersiapkan warga Negara yang cerdas, bertanggung jawab, dan keberadaban.

Pendidikan Kewarganegaraan merupakan sarana untuk membekali para peserta didik dengan pengetahuan dan kemampuan dasar berkenaan dengan hubungan antara warga Negara dengan warga Negara serta pendidikan pendahuluan bela Negara agar menjadi warga Negara yang dapat di andalkan oleh bangsa dan Negara. Pendidikan Kewarganegaraan memiliki peran penting dalam suatu kehidupan bangsa dan Negara. Pendidikan Kewarganegaraan bertujuan untuk membentuk individu-individu suatu Negara agar senantiasa selalu dipengaruhi 
oleh nilai-nilai dan tujuan pendidikan sebagai factor structural utama.

Istilah lain dari Pendidikan Kewarganegaraan disebut dengan Civic Education yang dikenal di beberapa Negara. Sebagai bidang ilmiah, Pendidikan Kewarganegaraan bersifat multi disipliner atau antar bidang bukan mono disipliner, karena kumpulan pengetahuan yang membangun ilmu kewarganegaraan di ambil dari berbagai disiplin ilmu. Oleh karena itu upaya pembahasan dan pengembangan memerlukan sumbangan dari berbagai disiplin ilmu yang meliputi ilmu politik, ilmu hokum, ilmu filsafat, ilmu sosiologi, ilmu administrasi negara, dan sejarah perjuangan bangsa dan ilmu budaya. Pendidikan Kewarganegaraan memberdayakan warga negara untuk dapat membuat pilihan yang bijak dan penuh dengan kesadaran dari berbagai alternative yang ditawarkan, memberikan pengalaman-pengalaman dan pemahaman yang dapat memupuk berkembanganya komitmen yang benar terhadap nilai-nilai kebudayaan dan sosial guna menuju masyarakat yang bermartabat serta menanamkan partisipasi yang berkompeten dan bertanggung jawab yang di dasarkan pada refleksi pengetahuan dan tanggung jawab moral. Tujuan pendidikan Kewarganegaraan adalah untuk mendidik peserta didik agar kelak menjadi warga Negara yang baik serta berguna bagi masyarakat dan Negara, Warga Negara yng tahu akan hak dan kewajibanya, warga Negara yang tahu akan nilai-nilai kemerdekaan, nilai-nilai kebenaran dan keadilan serta sangup membela dan memperjuangkanya, warga Negara yang cinta tanah air, bangsa Negara dan kebudayaanya, baik dari luar maupun dari dalam. Jadi tujuan belajar Pendidikan Kewarganegaraan akan berhasil apabila peserta didik bersikap sesuai dengan hak dan kewajibanya seperti yang di ajarkan dalam mata pelajaran Pendidikan Kewarganegaraan.

Pendidikan Pancasila dan Kewarganegaraan juga memiliki beberapa fungsi yakni yang pertama, mengembangkan dan melestarikan nilai moral pancasila secara dinamis dan terbuka. Dinamis dan terbuka berarti bahwa nilai moral yang dikembangkan mampu menjawab tantangan perkembangan yangterjadi dalam masyarakat, tanpa kehilangan jati diri sebagai bangsa Indonesia yang merdeka, bersatu, dan berdaulat. Kedua, mengembangkan dan membina manusia Indonesia seutuhnya yang sadar pilitik dan konstitusi Negara kesatuan Republik Indonesia berlandaskan Pancasila dan UUD 1945. Ketiga, membina pemahaman dan kesadaran terhadap hubungan antara warga Negara dengan warga Negara, antara warga Negara dengan Negara, pendidikan pendahuluan bela Negara agar mengetahui dan mampu melaksanakan dengan baik hak dan kewajiban sebagai warga Negara.

Hasil penelitian terhadap materi Pendidikan Kewarganegaraan mampu membentuk karakter peserta didik, diperoleh nilai sebagai berikut: Rentang nilai adalah 26 dengan sekor tertinggi 106 dan sekor terendah 80, yang diperoleh dari jumlah keseluruhan yang di dasarkan 
nilai kuesioner peserta didik. banyak kelas 6 , dengan panjang interval 4 , perolehan sekor rata-rata (mean) adalah 95.6, nilai tengah (median) sebesar 97.9 , perolehan modus sebasar 83.5, dan simpangan baku (standar deviasi) sebesar 6,9.

\section{Deskripsi Variabel Y (Karakter Peserta didik)}

Karakter adalah watak, tabiat, akhlak, atau kepribadian sesorang yang terbentuk dari hasil internalisasi berbagai kebajikan yang diyakini dan digunakan sebagai landasan untuk cara pandang, cara berpikir, bersikap, dan bertindak" (Koesuma: 124). Karakter juga merupakan kekuatan yang dapat membentengi diri dari segala macam godaan yang mendorong pada tingkah laku tidak terpuji Karakter adalah realisasi perkembangan positif sebagai individu (intelektual, perilaku, etika, sosial, dan emosional). Individu yang baik dan berkarakter adalah seseorang yang berusaha melakukan hal-hal yang terbaik terhadap Tuhan YME, dirinya sendiri, sesama, lingkungan, bangsa dan negara serta dinia Internasional pada umumnya dengan mengotimalkan potensi (pengetahuan) dirinya dan di sertai dengan kesadaraan, emosi, dan motivasinya (perasaanya).

Karater merupakan kekayaan terbesar dalam kehidupan seseorang. Karakter adalah kekuatan yang membentengi diri kita dari segala macam godaan yang mendorong pada tingkah laku tidak terpuji. Pembentukan pendidikan karakter bukanlah hal baru di Indonesia. Jauh sebelum kemerdekaan, Bapak Pendidikan
Indonesia yaitu Ki Hajar Dewantara menyebutkan bahwa pendidikan adalah daya upaya memajukan budi pekerti (kekuatan batin, karakter), Pikiran (intellect), dan tubuh anak. Bagian-bagian itu tidak boleh di pisahkan agar kita dapat memajukan kesempurnaan hidup anak kita. Jadi jauh-jauh Ki Hajar Dewantara sudah mengingatkan bahwa salah satu potensi yang harus dikembangkan pada peserta didik adalah karakter.

Di era Presiden pertama Indonesia, Bapak Ir.Soekarno, pembangunan kerakter di kenal dengan konsep Nation and Character Building. Bapak Soekarno berpesan bahwa tugas berat setelah kemerdekaan adalah pembangunan karakter. Jika pembangunan karakter tidak berhasil maka bangsa Indonesia menjadi bangsa kuli, demikian halnya dikatakanoleh bapak presiden Soekarno semasa hidupnya. Mengapa pendidikan karakter bagi bangsa kita sangat mendesak di terapkan pada peserta didik dari Taman Kanak-kanak (TK) sampai Perguruan Tinggi (PT) hal ini di karenakan sebagai bangsa yang beradab kini di pertanyakan karena munculnya sejumlah kasus yang berada di luar akal sehat kita. Yang membuat kita prihatin adalah orang-orang yang melakukanya adalah orang yang berpendidikan. Seperti makelar kasus, penggelapan pajak, dan korupsi yang sudah tidak asing lagi. Kondisi karakter bangsa Indonesia saat ini berada pada titik yang tidak menggembirakan. Kejahatan yang dilakukan bukan tanpa kesadaran bahkan di lakukan secara berencana dan sistematik. Maka pentingnya pendidikan 
dan pembangunan karakter bangsa yang unggul, tercermin dari moral, etika dan budi pekerti yang baik, semangat tinggi, tekad, dan energi yang kuat.

Pembangunan karakter dan pendidikan karakter menjadi suatu keharusan karena pendidikan tidak hanya menjadikan peserta didik menjadi cerdas. Tapi, juga mempunyai budi pekerti dan sopan santun sehingga keberadaanya sebagai anggota masyarakat nanti menjadi bermakna baik bagi dirinya maupun orang lain. Untuk itu, selain guru, orang tua juga mempunyai peranan yang sangat vital untuk menempah karakter peserta didik. Intinya, pendidikan karakter harus di lakukan di semua lini. Tidak hanya dunia pendidikan tapi juga lingkungan keluarga dan masyarakat.

Data pembentukan karakter peserta didik diperoleh dari nilai raport. Berdasarkan data penelitian yang diperoleh yaitu sebagai berikut: data tertinggi 87 sedangkan data terendah 59 . Perolehan rata-rata (Mean) sebesar 73,2 dan nilai tengah (median) 74,2 nilai modus sebesar 75,55 serta standar deviasi sebesar 5,89. Ukuran pemusatan dari data di atas diuraikan sebagai berikut:

a. Data tertinggi $=87$ dan data terendah 59; dan

b. Rentang $(\mathrm{R})=87-59=28$

\section{Pengujian Persyaratan Analisis Data}

\section{Uji normalitas}

Hasil perhitungan normalitas variabel $\mathrm{X}$ adalah sebesar 0,1088. Perbandingan hasil $l_{\text {hitung }}$ terhadap $1_{\text {tabel }}$ dilakukan dengan $\mathrm{N}=34$ dan taraf signifikan $\mathrm{a}=0,05$ pada table liliefors yakni $1_{\text {hitung }}<1_{\text {tabel }}(0,1088<$ 0,151 ) adalah lebih kecil. Hal ini berarti Ho ditolak karena data variabel $\mathrm{X}$ berasal dari populasi berdistribusi tidak normal. Hasil perhitungan normalitas variabel $Y$ adalah sebesar 0,1140. Perbandingan hasil $1_{\text {hitung }}$ terhadap $1_{\text {tabel }}$ dilakukan dengan $\mathrm{N}=$ 34 dan taraf signifikan $a=0,05$ pada table liliefors yakni $0,1140<0,151$ adalah lebih kecil. Hal ini berarti Ho ditolak karena data variabel $\mathrm{Y}$ berasal dari populasi berdistribusi tidak normal. Maka dengan demikian uji normalitas sebagai uji persyaratan analisis data untuk variabel $\mathrm{X}$ (materi pendidikan Kewarganegaraan) dan variabel Y(karakter peserta didik) adalah kedua data berasal dari populasi yang berdistribusi normal.

\section{Uji linieritas}

Perhitungan uji linieritas terhadap Materi Pendidikan Kewarganegaraan mampu membentuk karakter peserta didik, pertama dilakukan dengan melakukan uji perhitungan uji linearitas regresi $\mathrm{Y}$ atas $\mathrm{X}$ dengan hasil yang diperoleh bahwa Jadi disimpulkan bahwa $\mathrm{H}_{\mathrm{o}}: \mathrm{Y}=\mathrm{a}+\beta \mathrm{X}$ ( regresi linier), $\mathrm{H}_{\mathrm{a}}: \mathrm{Y} \neq$ $\beta \mathrm{X}$ (regresi tidak linier) dengan perolehan $F_{\text {hitung }}-79,77$ dan $F_{\text {tabel }}(0,05)$ 1,461, jadi dapatdisimpulkan bahwa Ho diterima karena regresi $\mathrm{Y}$ atas $\mathrm{X}$ adalah linier, yaitu $\mathrm{F}_{\text {hitung }}-79,77<\mathrm{F}_{\text {tabel }} 1,46$. Selanjutnya dengan melakukan uji signifikansi regresi $\mathrm{Y}$ atas $\mathrm{X}$ dengan kriteria sebagai berikut $\mathrm{H}_{\mathrm{o}}$ : $\beta=0$ (regresi tak signifikan) $\mathrm{H}_{\mathrm{a}}: \beta>0$ (regresi signifikan) maka dapat disimpulkan bahwa $F_{\text {hitung }} 1,5$ lebih besar dari $F_{\text {table }}$ 
$(0,05)$ yaitu 0,03 . Dengan demikian dapat disimpulkan bahwa $\mathrm{H}_{\mathrm{a}}$ diterima karena regresi $\mathrm{Y}$ atas $\mathrm{X}$ adalah linier, yaitu $\mathrm{F}_{\text {hitung }}$ $1,5>\mathrm{F}_{\text {tabel }} 0,03$.

\section{Pengujian Hipotesis}

\section{Uji korelasi data}

Hasil pengujian hipotesis yang digunakan untuk mengukur seberapa besar pengaruh variabel $\mathrm{X}$ terhadap variabel Y, menggunakan korelasi product moment adalah sebesar 2,345 perbandingan hasil $r_{\text {hitung }}$ terhadap $r_{\text {tabel }}$ dilakukan dengan $\mathrm{N}=34$ dan taraf signifikansi 0,05 pada table product moment diperoleh hasil bahwa $r_{\text {hitung }}$ lebih besardari $r_{\text {table }}$ yaitu 2,345 $>0,339$. Dengan demikian antara variabel $\mathrm{X}$ (materi pendidikan kewarganegaraan) dengan variabel Y (karakter peserta didik) adalah berkorelasi positif atau mempunyai keterkaitan hubungan satu sama lain.

\section{Uji keberartian hubungan}

Berdasarkan hasil $r_{\text {hitung }}$ sebesar 2,345 diatas maka dapat dilakukan uji keberartian hubungan dan koefisien determinasi. Hasil perhitungan keberartian hubungan 5,96. Perbandingan hasil $t_{\text {hitung }}$ terhadap $t_{\text {tabel }}$ dilakukan dengan $\mathrm{N}=34$ dan taraf signifikan 0,05 pada table nilai dalam distribusi t yakni 5,96 > 1,679 adalah lebih besar atau variabel $\mathrm{X}$ dan variabel $Y$ memiliki keberartian hubungan.

\section{Uji Koefisien Determinasi}

Untuk menguji berapa persen pengaruh variabel X ( materi Pendidikan kewarganegaraan) terhadap variabel $\mathrm{Y}$ (karakter peserta didik), maka dilakukan uji keberartian hubungan atau koefisien determinasi. Hasil perhitungan koefisien determinasi antara variabel $\mathrm{X}$ dengan variabel $Y$ sebesar 54,99\%. Hal ini menunjukan bahwa variabel $\mathrm{X}$ mempunyai kontribusi keterkaitan faktor terhadap variabel Y sebesar 54,99\%.

\section{KESIMPULAN}

Kesimpulan dari hasil penelitian tentang hubungan materi pendidikan kewarganegaraan mampu membentuk karakter peserta didik di MTs swasta di daerah Pamulang Kota Tangerang Selatan, adalah Terdapat hubungan positif antara Materi Pendidikan Kewarganegaraan mampu membentuk karakter peserta didik di MTs Daarul Hikmah Pamulang Kota Tangerang Selatan. Hal ini didasarkan pada perbandingan hasil $r_{\text {hitung }}$ terhadap $r_{\text {tabel }}$ yang dilakukan dengan $\mathrm{N}=$ 34 dan taraf signifikan 0,05 pada table product moment yaitu 2,345 >0,339 atau secara statistika menunjukan $r_{\text {hitung }}$ lebih besar dari pada $r_{\text {tabel. }}$ Selanjutnya untuk mengetahui tingkat keberartian kedua variabel tersebut diperoleh hasil $t_{\text {hitung }}$ pada taraf signifikansi $(a)=0,05$ sebesar 5,96 dan $t_{\text {tabel }}$ 1,697 dengan demkian $t_{\text {hitung }}$ lebih besar daripada $t_{\text {tabel }}(5,96>1,697)$. Hasil ini menunjukan bahwa koefisien korelasi product moment signifiken positif yang searah. Dalam hal ini mempunyai kesimpulan bahwa materi pendidikan kewarganegaran mampu membentuk karakter peserta didik. 
Berdasarkan kesimpulan hasil penelitian di atas membuktikan bahwa terdapat pengaruh antara materi pendidikan kewarganegaraan sebagai salah satu faktor yang mampu membentuk karakter peserta didik di MTs Daarul Hikmah Pamulang Kota Tangerang Selatan sebesar 54,99\%, maka hal ini menunjukan masih ada sebesar $45,01 \%$ faktor-faktor lain yang kemungkinan dapat memp 59 terbentuknya karakter peserta MTs Daarul Hikmah Pamulang. Maka implikasinya adalah untuk meningkatkan lebih karakter peserta didik upaya yang dilakukan bukan hanya meningkatkan materi Pendidikan Kewarganegaraan saja, tetapi upaya lain juga dirasa perlu, seperti halnya perbaikan sistem penilaian dan pengukuran bidang studi pendidikan kewarganegaran. Keteladanan guru, nasihat orang tua, pengaruh lingkungan pergaulan peserta didik, dan kegiatankegiatan sosial. Perbaikan sarana belajar disekolah maupun dirumah, mengefektifkan cara belajar yang sesuai dengan taraf perkembangan peserta didik. Penyesuaian pendekatan, metode serta teknik pembelajaran yang sesuai dengan materi pembelajaran dan keadaan peserta didik.

\section{REFERENSI}

Ahmadi, Dkk. 1991. Prestasi Siswa di Sekolah. Jakarta: Grasindo, Jakarta.

John, A. 2010. Membangun Karakter Tangguh. Surabaya: Portico Publishing.

Koesoema A, D. 2007. Strategi Mendidik Anak di Zaman Global. Jakarta: Grasindo.

Kaelan, MS. 2007. Pendidikan Kewarganegaraan. Yogyakarta: Paradigma.

Kansil, C.S.T. 2000. Pendidikan Pancasila dan Kewarganegaraan. Jakarta: Erlangga.

Karnadi. 2006. UURI No.14 Tahun 2005 Tentang Guru dan Dosen. Jakarta: Cipta Jaya.

Yudha, P. 2009. UURI Tentang Sistem Pendidikan Nasional No.20 Tahun 2003. Jakarta: Karya Gemilang.

Made, P. 2007. Landasan Pendidikan Stimulus Ilmu Pendidikan Bercorak Indonesia. Jakarta: Rineka Cipta.

Megawangi, R. 2007. Semua Berakar Dari Kaerakter. Jakarta: Lembaga Penerbit FEUI.

Sentosa, S. 2008. Sistem Pendidikan Nasional. Bandung: Nuansa Aulia.

Sugiono. 2010. Statistika Untuk Penelitian. Bandung: Alfabeta.

Rosyidi, U. 2011. Reformasi Birokrasi Pendidikan. Jakarta: Suara Guru. 